\title{
Serosurvey for selected pathogens in Iberian roe deer
}

Mariana Boadella', Tania Carta', Álvaro Oleaga ${ }^{1,4}$, Gerardo Pajares², Marta Muñoz ${ }^{3}$, Christian Gortázar ${ }^{1 *}$

\begin{abstract}
Background: The roe deer is the most abundant and widespread wild Eurasian cervid. Its populations are expanding and increasingly in contact with livestock. This may affect the distribution of infectious diseases shared with other wild and domestic ungulates.

Methods: We investigated the antibody seroprevalence against Pestivirus, Herpesvirus, Bluetongue (BT) virus, M. avium paratuberculosis (MAP), and Brucella sp. in 519 roe deer from different regions in Spain, south-western Europe.

Results: No antibodies were detected against BT and Brucella sp. However, antibodies were detected against Pestivirus (1.5\%), Herpesvirus (0.2\%) and MAP (9.2\%). MAP antibodies were detected in seven of the eight populations (range $5-16.4 \%$ ).

Conclusions: The detection of MAP antibodies in samples from most roe deer populations suggests that contact with MAP is widespread in this wildlife species. The highest prevalence was detected in sites with abundant dairy cattle and frequent use of liquid manure on pastures. Considering the results obtained regarding exposure to different pathogens, we suggest that antibody prevalences in this non-gregarious browser are largely determined by environmental factors, potentially modulating vector populations or pathogen survival in the environment.
\end{abstract}

\section{Background}

Interactions between domestic and wild ungulates represent a potential problem in epidemiology [1], but little is known about the role of roe deer (Capreolus capreolus) in some diseases of concern in livestock. The roe deer is a Eurasian wild cervid whose populations have been expanding during the last decades across Europe, both in density and in geographical range [2,3]. These demographic and geographic changes may increase the risk of acquiring new diseases through both increased contact rates with other species, and increased intra-specific contact and density-dependent impact on individual fitness at higher densities [4,5]. Expansion of roe deer may have an influence in the epidemiology of several infectious diseases potentially shared with other native wild ungulates, domestic ungulates, and even human beings [1].

In Europe, several serologic surveys have been carried out in order to investigate the sanitary status of roe deer

\footnotetext{
* Correspondence: christian.gortazar@uclm.es

${ }^{1}$ IREC (CSIC-UCLM-JCCM), Ronda de Toledo s/n, 13071 Ciudad Real, Spain Full list of author information is available at the end of the article
}

in different countries and situations. These surveys have reported on Pestivirus and Herpesvirus, paratuberculosis and other bacterial diseases, and protozoa mainly including Toxoplasma gondii and Neospora caninum. However, only limited knowledge exists regarding diseases of roe deer from the Iberian Peninsula.

Infections with bovine viral diarrhea virus (BVDv), a Pestivirus, are widespread throughout the world. Although infection prevalence varies among surveys, the infection tends to be endemic in cattle, reaching a maximum level of $1 \%$ persistently infected (PI) and 60\% antibody positive cattle. PI cattle are the main source for transmission of the virus [6]. In the US, white-tailed deer (Odocoileus virginianus) can get infected from cattle and give birth to PI fawns that may interfere with control programs [7]. In Europe, BVDv-like Pestivirus was isolated from two seronegative roe deer in Germany [8] and $12 \%$ seroprevalence was found in roe deer from Norway [9]. However, no Pestivirus seropositive roe deer were found in several recent surveys in Germany [10], Austria [11] and Italy [12,13]. Two studies carried out in the Spanish Pyrenees showed no antibody
C Biomed Central

() 2010 Boadella et al; licensee BioMed Central Ltd. This is an Open Access article distributed under the terms of the Creative Commons Attribution License (http://creativecommons.org/licenses/by/2.0), which permits unrestricted use, distribution, and reproduction in any medium, provided the original work is properly cited. 
seroprevalence in 21 and 43 roe deer tested against these viruses $[14,15]$.

Of the ruminant alpha-herpesviruses, Bovine Herpesvirus $1(\mathrm{BHV}-1)$ is the best characterized one and responsible for infectious bovine rhinotracheitis (IBR). However, other cross-serological related alpha-herpesviruses have been isolated from cervids [16]. Roe deer have been included in Bovine Herpesvirus serosurveys in Germany [10], Italy [12] and Norway [9], showing mean serum antibody prevalences of $10 \%, 0 \%$ and $3 \%$ respectively.

The possible role of wild ruminants, notably deer, in bluetongue epidemiology is a matter of increasing concern in Europe. Recent surveys reported low $(\leq 5 \%)$ prevalence of bluetongue (BT) antibodies in roe deer from Spain [17], and from Belgium [18]. Despite this, the role of European wild ruminants in the epidemiology of BTV remains still unclear.

Regarding bacterial diseases, wild ruminants are susceptible to paratuberculosis, a disease caused by $\mathrm{Myco-}$ bacterium avium paratuberculosis (MAP) $[19,20]$. Previous studies on MAP revealed an antibody seroprevalence up to $13 \%$ in roe deer from North-Western Italy and Norway $[20,21]$. In the Czech Republic, MAP infection was confirmed in $0.2 \%$ [19] and in Italy in $22 \%$ of roe deer examined [21]. A recent serosurvey on MAP antibodies, using the PPA3 antigen ELISA, revealed 3\% prevalence in cattle from north-western Spain [22]. However, there is no information on paratuberculosis in roe deer from Spain.

In Spain, brucellosis in domestic ruminants is almost eradicated, and its prevalence in bovine (caused by $B$. abortus), caprine and ovine (caused by B. melitensis) herds has decreased from $1.3 \%$ and $12 \%$ in 2001 to $0.7 \%$ and $2.8 \%$ in 2007 , respectively (http://rasve.mapa.es, last access 16/04/2010). It is believed that wild ruminants are occasional victims of brucellosis "spill-over" from livestock, rather than true reservoirs [1,23-25].

Contact with other infectious diseases recently reported in European roe deer includes papillomavirus [26], Q fever [27], chlamydiophilosis [28] and anaplasmosis [29]. Finally, several studies reported on antibodies against Toxoplasma gondii [12,30-36] and against Neospora caninum [12,36,37].

The roe deer is a selective browser and less gregarious than other deer species [38,39], the pasture sharing and contact with domestic cattle is low and disease maintenance is less likely [40]. Therefore, we hypothesized that roe deer would not be an important species for wildlife disease surveillance [41]. In contrast, we expect a different scenario with diseases not associated with behavior, such as vector borne diseases. The aim of this serosurvey was determining the seroprevalence of antibodies against Pestivirus, Herpesvirus, Bluetongue virus, MAP, and Brucella sp. in roe deer from different areas of Spain in order to infer the role that this species can play in their epidemiology.

\section{Methods}

\section{Animal sampling}

Our study area was the Iberian Peninsula in south-western Europe. For the study, eight geographic sampled populations were defined (Figure 1). Sampling took place during an eight-year period, from hunting season $2000 / 2001$ to $2008 / 2009$, and was opportunistic and biased towards the main hunting season (summer). Blood from hunter-harvested animals was drawn from the heart or the thoracic cavity during field necropsies. Serum was obtained after centrifugation and stored at $-20^{\circ} \mathrm{C}$ until analyzed. When possible, lymph nodes were collected and stored at $-20^{\circ} \mathrm{C}$ for PCR testing. Sex and age were determined; the latter according to tooth eruption patterns [42]. Animals $<1$ year of age were classified as calves, and those $>1$ year of age as adults. Sex $(\mathrm{n}=458)$ and age $(\mathrm{n}=464)$ could be recorded for most animals. Due to hunting origin, the sample was biased towards adult males $(\mathrm{n}=301)$.

\section{Laboratory techniques}

Serologic tests and techniques employed are summarized in Table 1. In some cases, insufficient volume of sera did not allow testing for antibodies against all pathogens (Table 2). In order to verify the presence of pathogens, 49 roe deer sera from seropositive areas were tested by means of a sandwich ELISA that detects the BVD/MD/BD p125/p80 protein. Lymph node samples from five PPA3 ELISA seropositive roe deer were tested for the repetitive insertion sequence IS900 of Mycobacterium avium paratuberculosis by PCR (Adiavet paraTB, Adiagene, Saint-Brieuc, France; [43]).

\section{Statistics}

We used Sterne's exact method to estimate prevalence confidence intervals. Prevalence comparisons among categories were done with homogeneity tests [44]. Data was analyzed using the SPSS statistical package, version 17.0 (SPSS Inc., Chicago, IL, USA).

\section{Results}

The frequencies of antibody response against different pathogens are summarized in Table 2. No antibodies were detected against BT and Brucella sp. However, antibodies were detected against Pestivirus (1.5\%), Herpesvirus $(0.2 \%)$ and MAP (9.2\%). MAP antibodies were detected in seven of the eight populations. Local prevalence was up to $16.4 \%$ in population A (Coruña; Table 2). Only one animal was seropositive for more than one pathogen (MAP and Pestivirus). When analyzing MAP 


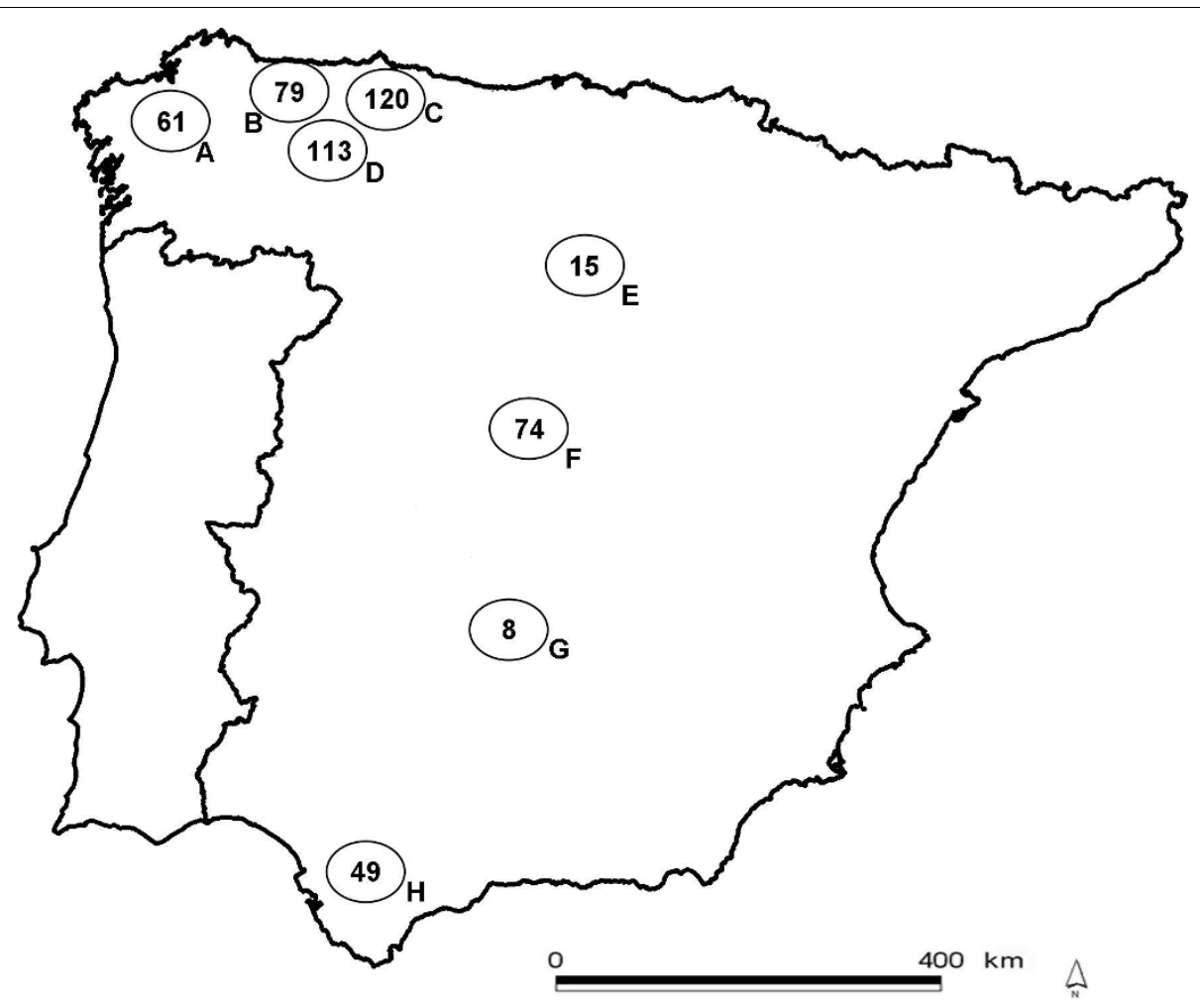

Figure 1 In circles, the eight defined sampling populations with the number of sampled animals in each. A, Coruña; $B$, Occidental Cantabrian Coast; C, Oriental Cantabrian Coast; D, Cantabrian mountains; E, Iberian mountains; F, Central mountains; G, Toledo mountains; H, Alcornocales.

seroprevalences by age and sex, no statistically significant differences were found (Fischer exact test, $\mathrm{p}>0.05$ in both cases). No MAP DNA was detected by PCR in the five PPA3 ELISA positive roe deer tested. Mean Pestivirus antigen prevalence in the seropositive areas was $16.3 \%$ (95\% IC, 7.6-29.4).

\section{Discussion}

This is the first large-scale survey on infectious disease agents in Iberian roe deer. Results reported herein confirm our initial hypothesis that roe deer display lower prevalence of antibodies against viral and bacterial diseases [12], as compared to other wild ruminants $[17,27,43]$. One possible explanation could be that differences in social behaviour between roe deer and other Iberian wild ruminants, such as red and fallow deer, would lead to fewer intra-specific contacts. Roe deer are seasonally territorial, solitary, and have smaller home ranges than red and fallow deer. Differences in feeding behaviour (roe deer are concentrate selectors and

Table 1 Serologic tests employed for serological assay of roe deer sera sampled

\begin{tabular}{|c|c|c|c|c|}
\hline Agent (group) & Test & Antigen & Conjugate & Reference \\
\hline \multirow[t]{2}{*}{ BVDv/BDv (Pestivirus) } & $\begin{array}{l}\text { ELISA; SERELISA }{ }^{\circledR} \text { BVD/BD p80 Ab. Mono Blocking, Synbiotics; } \\
\text { Lyon, France. }\end{array}$ & protein p80/125 & $\begin{array}{l}\text { None (blocking } \\
\text { test) }\end{array}$ & {$[9]$} \\
\hline & $\begin{array}{l}\text { ELISA; SERELISA }{ }^{\oplus} \text { BVD/BD p } 80 \text { Ag. Mono Indirect, Synbiotics; } \\
\text { Lyon, France. }\end{array}$ & None & $\begin{array}{l}\text { Goat } A b \text { anti- } \\
\text { rabbit } \\
\text { lg/peroxidase }\end{array}$ & {$[15]$} \\
\hline IBRv (Herpesvirus) & $\begin{array}{l}\text { ELISA; SERELISA }{ }^{\oplus} \text { IBR/IPV Ab. Mono Indirect Synbiotics; Lyon, } \\
\text { France. }\end{array}$ & glycoprotein gB & $\begin{array}{l}\text { MAb anti-bovine } \\
\text { lgG/peroxidase }\end{array}$ & {$[12]$} \\
\hline Bluetongue virus & Ingezim BTV Compac 2.0 12.BTV.K3${ }^{\circledR}$, Ingenasa; Madrid, Spain. & recombinant VP7 & $\begin{array}{l}\text { None (blocking } \\
\text { test) }\end{array}$ & {$[58]$} \\
\hline $\begin{array}{l}\text { M. avium } \\
\text { paratuberculosis }\end{array}$ & ELISA; In-house modified including positive controls. & $\begin{array}{l}\text { PPA-3 } \\
\text { (Allied Monitor, Fayette, MO, } \\
\text { USA) }\end{array}$ & $\begin{array}{l}\text { Protein-G/ } \\
\text { peroxidase }\end{array}$ & {$[43]$} \\
\hline Brucella sp. & Rose Bengal agglutination test & Rose Bengal Brucella Antigen & None & {$[59]$} \\
\hline
\end{tabular}


Table 2 Serologic prevalence of selected infectious diseases in roe deer sampled, according to the eight sampling populations

\begin{tabular}{|c|c|c|c|c|c|c|c|c|c|c|c|}
\hline \multirow[t]{3}{*}{ Population } & \multirow{3}{*}{$\begin{array}{c}\text { Sera } \\
\text { analyzed }\end{array}$} & \multicolumn{2}{|c|}{ Pestivirus } & \multicolumn{2}{|c|}{ Herpesvirus } & \multicolumn{2}{|r|}{ BTV } & \multicolumn{2}{|r|}{ MAP } & \multicolumn{2}{|c|}{ Brucella } \\
\hline & & Sera* & $\begin{array}{c}\text { Prevalence } \\
\text { (\%) }\end{array}$ & Sera* & $\begin{array}{c}\text { Prevalence } \\
\text { (\%) }\end{array}$ & Sera* & $\begin{array}{c}\text { Prevalence } \\
\text { (\%) }\end{array}$ & Sera* & $\begin{array}{c}\text { Prevalence } \\
\text { (\%) }\end{array}$ & Sera* & $\begin{array}{c}\text { Prevalence } \\
\text { (\%) }\end{array}$ \\
\hline & & & $95 \% \mathrm{Cl}$ & & $95 \% \mathrm{Cl}$ & & $95 \% \mathrm{Cl}$ & & $95 \% \mathrm{Cl}$ & & $95 \% \mathrm{Cl}$ \\
\hline A & 61 & $0 / 61$ & $\begin{array}{c}0 \\
(0-4.87)\end{array}$ & $0 / 61$ & $\begin{array}{c}0 \\
(0-4.87)\end{array}$ & $0 / 21$ & $\begin{array}{c}0 \\
(0-15.8)\end{array}$ & 10/61 & $\begin{array}{c}16.4 \\
(8.74-27.74)\end{array}$ & $0 / 42$ & $\begin{array}{c}0 \\
(0-8.92)\end{array}$ \\
\hline B & 79 & $1 / 79$ & $\begin{array}{c}1.3 \\
(0.07-6.75)\end{array}$ & $0 / 79$ & $\begin{array}{c}0 \\
(0-4.75)\end{array}$ & $0 / 27$ & $\begin{array}{c}0 \\
(0-12.38)\end{array}$ & $8 / 79$ & $\begin{array}{c}10.1 \\
(4.76-18.84)\end{array}$ & $0 / 37$ & $\begin{array}{c}0 \\
(0-9.05)\end{array}$ \\
\hline C & 120 & $2 / 120$ & $\begin{array}{c}1.7 \\
(0.03-6.06)\end{array}$ & $0 / 120$ & $\begin{array}{c}0 \\
(0-3.13)\end{array}$ & $0 / 16$ & $\begin{array}{c}0 \\
(0-20.83)\end{array}$ & $6 / 120$ & $\begin{array}{c}5 \\
(2.2-10.69)\end{array}$ & $0 / 30$ & $\begin{array}{c}0 \\
(0-11.15)\end{array}$ \\
\hline D & 113 & $2 / 113$ & 1.8 & $0 / 113$ & 0 & $0 / 42$ & 0 & $\begin{array}{l}11 / \\
113\end{array}$ & 9.7 & $0 / 26$ & 0 \\
\hline & & & $(0.03-6.44)$ & & $(0-3.32)$ & & $(0-8.92)$ & & $(5.16-16.7)$ & & $(0-12.85)$ \\
\hline$E$ & 15 & $0 / 15$ & $\begin{array}{c}0 \\
(0-22.22)\end{array}$ & $1 / 15$ & $\begin{array}{c}6.7 \\
(0.35-30.2)\end{array}$ & $0 / 14$ & $\begin{array}{c}0 \\
(0-23.81)\end{array}$ & $2 / 15$ & $\begin{array}{c}13.3 \\
(2.43-39.67)\end{array}$ & $0 / 10$ & $\begin{array}{c}0 \\
(0-29.08)\end{array}$ \\
\hline $\mathrm{F}$ & 74 & $3 / 74$ & $\begin{array}{c}4.1 \\
(1.12-11.29)\end{array}$ & $0 / 71$ & $\begin{array}{c}0 \\
(0-4.79)\end{array}$ & $0 / 41$ & $\begin{array}{c}0 \\
(0-8.17)\end{array}$ & $7 / 74$ & $\begin{array}{c}9.46 \\
(4.53-18.72)\end{array}$ & $0 / 19$ & $\begin{array}{c}0 \\
(0-17.65)\end{array}$ \\
\hline G & 8 & $0 / 8$ & $\begin{array}{c}0 \\
(0-37.71)\end{array}$ & $0 / 8$ & $\begin{array}{c}0 \\
(0-36.46)\end{array}$ & $0 / 1$ & $\begin{array}{c}0 \\
(0-94.99)\end{array}$ & $0 / 8$ & $\begin{array}{c}0 \\
(0-36.46)\end{array}$ & $0 / 7$ & $\begin{array}{c}0 \\
(0-37.71)\end{array}$ \\
\hline $\mathrm{H}$ & 49 & $0 / 49$ & $\begin{array}{c}0 \\
(0-7.65)\end{array}$ & $0 / 49$ & $\begin{array}{c}0 \\
(0-7.65)\end{array}$ & $0 / 10$ & $\begin{array}{c}0 \\
(0-29.08)\end{array}$ & $4 / 49$ & $\begin{array}{c}8.2 \\
(2.84-19.18)\end{array}$ & $0 / 30$ & $\begin{array}{c}0 \\
(0-11.15)\end{array}$ \\
\hline Total & 519 & $8 / 519$ & 1.5 & $1 / 516$ & 0.2 & $0 / 172$ & 0 & $\begin{array}{l}48 / \\
519\end{array}$ & 9.2 & $0 / 201$ & 0 \\
\hline & & & $(0.05-3.04)$ & & $(0-1.1)$ & & $(0-2.18)$ & & $(7.01-12.11)$ & & $(0-1.87)$ \\
\hline
\end{tabular}

*positive sera/tested sera

browsers) could lead to less indirect inter-specific contacts $[18,38]$. However, it must be taken into account that sampling was biased towards males, and may thus not represent the actual health situation of the roe deer population. Although serosurveys have proven to be a fundamental tool for disease surveillance, interpretation of antibody results in this study has to be approached with caution due to the lack of specific controls for roe deer [45]. Sensitivity and specificity for the different ELISA tests in roe deer were not determined in our study.

Pestivirus antibody prevalence was low, similar to results reported in other studies on European roe deer $[11,13,14]$. This suggests that roe deer have limited contact with common Pestivirus. In Spain, Pestivirus infection in domestic ruminants has frequently been reported, with prevalences reaching values up to $83 \%$ $[14,46,47]$. However, in our study a comparatively high antigen prevalence was found in the seropositive populations. This result contrasts with similar studies on wild ruminants, where antigen prevalence was always lower than antibody prevalence $[48,49]$. A possible explanation could be the presence of a new Pestivirus in this species not detectable by the antibody ELISA used [13]. New strains of Pestivirus have been described in the past in roe deer [50]. A second and more plausible explanation would be false positive results of the antigen ELISA due to unspecific cross-reactions. In order to clarify these findings, the samples will be further analyzed by PCR and serum neutralization.

The low antibody prevalence found against Herpesvirus was probably also a reflection of the relative isolation of roe deer from domestic animals. IBR is endemic among bovine livestock in Spain, with herd prevalence of $40-50 \%$ although vaccination programs are implemented (http://rasve.mapa.es, last access 16/06/2010).

Concerning BT, we expected some level of antibody detection based on prior data on wild ruminants from Spain [17,51] and Belgium [18], and because of being a vector borne disease, a priori less dependent on social behaviour and food habits. Few roe deer in our sample were harvested in BT areas $(n=65)$. The possible reasons for the marked difference in BT seropositivity between roe deer and sympatric red deer (Cervus elaphus) are open for further research $[17,18]$.

Regarding brucellosis, results show that roe deer have no contact with Brucella sp. This confirms recent results from the Basque Country and Aragón, suggesting that roe deer constitute no reservoir host for livestock brucellosis in south-western Europe [25]. 
MAP is the pathogen with the highest antibody seroprevalence detected in our study. Serum antibody prevalence in the northern populations was lower than those reported in northern Spain in fallow deer (Dama dama) $[52,53]$ and in red deer [43], but similar to that found for Cantabrian chamois (Rupicapra pyrenaica parva) [54]. Roe deer from Galicia (population A) displayed the highest seroprevalence. One possible explanation could be the eventual infection of wild ruminants feeding on pastures irrigated with liquid manure from infected dairy cattle [55], combined with the prolonged environmental survival of mycobacteria at high humidity and limited sunshine [56]. Population A inhabits a humid region with high percentage of dairy cattle and frequent use of liquid manure in contrast to the rest of the sampled areas where dairy cattle and use of their manure is much less important. The detection of MAP antibodies in samples from 7 of 8 roe deer populations throughout Spain suggests that contact with MAP may be widespread in this wild ruminant. However, all 5 PCR tested seropositive roe deer showed to be negative for MAP DNA. Negative results in this low number of PCR-tested animals can not rule out some possible involvement of roe deer in the epidemiology of this disease, or at least some potential of the roe deer as an indicator of environmental contamination by MAP, as already suggested for toxoplasmosis [31]. If wild ruminants were able to excrete MAP in sufficient quantities, circulation of MAP in wildlife could eventually interfere with MAP eradication efforts in livestock [57].
In order to put together recent information regarding roe deer serosurveys in Spain, Figure 2 shows the prevalence reported by agent. The figure suggests that this species has little contact with viral disease agents and Brucella, but seroprevalence increases when dealing with other bacterial and protozoan diseases. Excepting $\mathrm{BT}$, vector-borne diseases have medium to high seroprevalence in roe deer. We suggest that antibody prevalences in roe deer are largely determined by environmental factors, potentially modulating vector populations or pathogen survival in the environment.

\section{Acknowledgements}

We thank Paqui Talavera, Joaquín Vicente, Isabel G. Fernández-de-Mera, José Antonio Ortiz, Cristina San José (E.R. Corzo Andaluz, Junta de Andalucía), José Antonio Gamarra and Fernando Horcajada for their help with field and laboratory work, Ezio Ferroglio for finding positive controls, Pelayo Acevedo for help with the figures and many hunters involved in getting the samples. This study is a contribution to grant AGL2008-03875 Plan Nacional MCINN and FEDER and the agreements with Ministerio de Medio Ambiente y Medio Rural y Marino (OAPN and SDGPP), Principado de Asturias, and Castilla-La Mancha. Mariana Boadella has a grant from the European Research Project 212417 "Strategies for the Eradication of Bovine

Tuberculosis, Tb-Step". The experiments and procedures included in this study comply with national and European laws. Sponsors had no role in the study design, in the collection, analysis and interpretation of data; in the writing of the manuscript; and in the decision to submit the manuscript for publication.

\section{Author details}

${ }^{1}$ IREC (CSIC-UCLM-JCCM), Ronda de Toledo s/n, 13071 Ciudad Real, Spain. ${ }^{2}$ Asociación del Corzo Español (UCM), Madrid, Spain. ${ }^{3}$ Conselleria do Medio Rural, Xunta de Galicia, Santiago de Compostela, Spain. ${ }^{4}$ SERIDA, Servicio Regional de Investigación y Desarrollo Agroalimentario, Laboratorio de Sanidad Animal, Gijón, Spain.

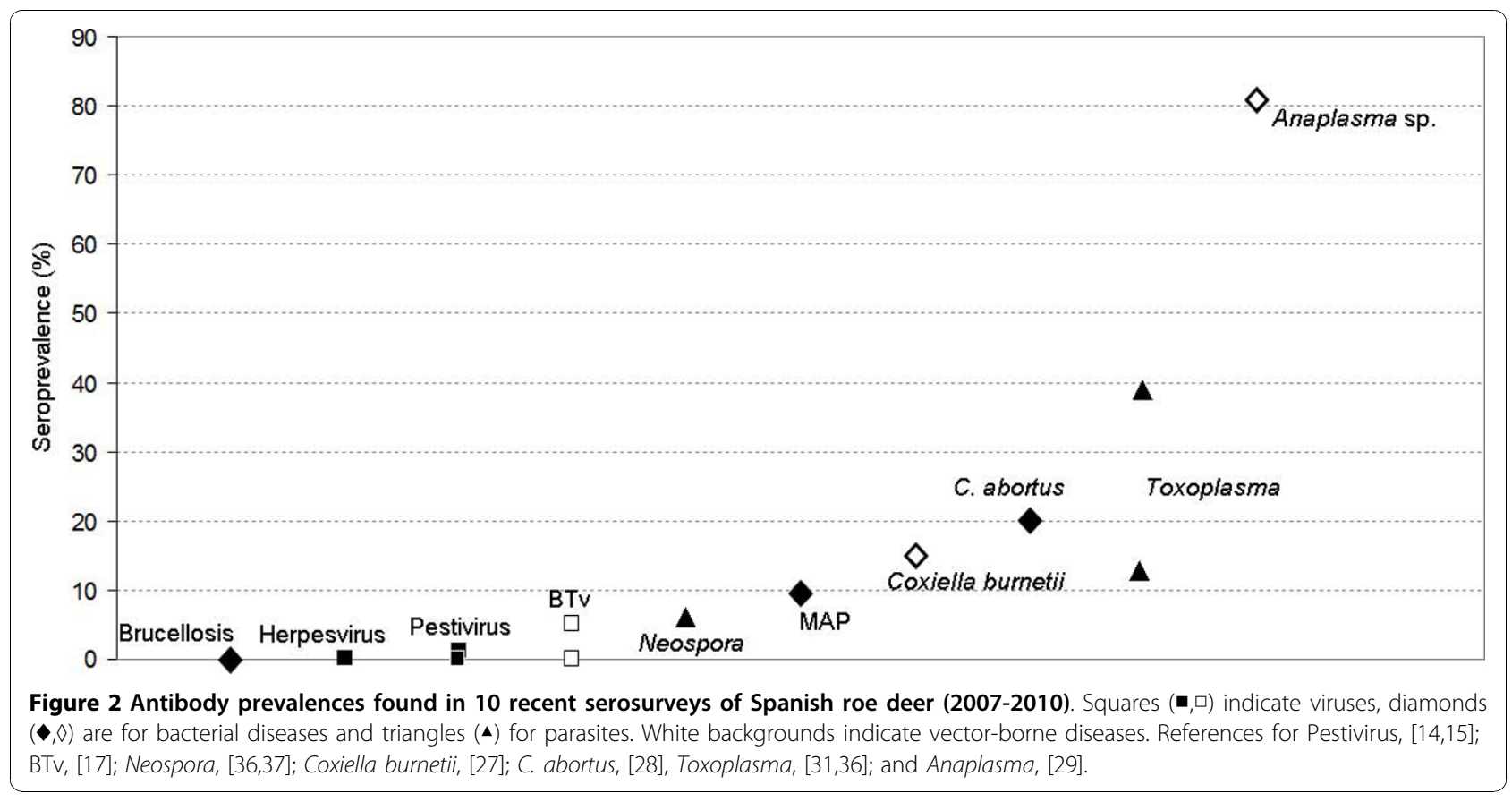




\section{Authors' contributions}

$\mathrm{AO}, \mathrm{GP}$ and $\mathrm{MM}$, performed the field work and collected the samples of the study. MB and TC carried out the laboratory work. MB and CG analyzed the data and drafted the manuscript. All authors read and approved the final manuscript.

\section{Competing interests}

The authors declare that they have no competing interests.

Received: 4 July 2010 Accepted: 16 November 2010 Published: 16 November 2010

\section{References}

1. Gortazar C, Ferroglio E, Hofle U, Frolich K, Vicente J: Diseases shared between wildlife and livestock: a European perspective. Eur J Wildl Res 2007, 53(4):241-256.

2. Gortazar C, Herrero J, Villafuerte R, Marco J: Historical examination of the status of large mammals in Aragon, Spain. Mammalia 2000, 64(4):411-422.

3. Acevedo P, Delibes-Mateos M, Escudero MA, Vicente J, Marco J, Gortazar C: Environmental constraints in the colonization sequence of roe deer (Capreolus capreolus Linnaeus, 1758) across the Iberian Mountains, Spain. J Biogeogr 2005, 32(9):1671-1680

4. Oleaga A, Balseiro A, Gortazar C: Sarcoptic mange in two roe deer (Capreolus capreolus) from northern Spain. Eur J Wildl Res 2008, 54(1):134-137.

5. Balseiro A, Oleaga A, Orusa R, Robetto S, Zoppi S, Dondo A, Goria M, Gortazar C, Marin JFG, Domenis L: Tuberculosis in roe deer from Spain and Italy. Vet Rec 2009, 164(15):468-470.

6. Houe H: Epidemiological features and economical importance of bovine virus diarrhoea virus (BVDV) infections. Vet Microbiol 1999, 64(2-3) 89-107.

7. Passler T, Walz PH, Ditchkoff SS, Brock KV, Deyoung RW, Foley AM, Daniel Givens M: Cohabitation of pregnant white-tailed deer and cattle persistently infected with Bovine viral diarrhea virus results in persistently infected fawns. Vet Microbiol 2009, 134(3-4):362-367.

8. Frölich $\mathrm{K}$, Hofmann M: Isolation of bovine viral diarrhea virus-like pestiviruses from roe deer (Capreolus capreolus). J Wildl Dis 1995, 31(2):243-246.

9. Lillehaug A, Vikoren T, Larsen IL, Akerstedt J, Tharaldsen J, Handeland K: Antibodies to ruminant alpha-herpesviruses and pestiviruses in Norwegian cervids. J Wildl Dis 2003, 39(4):779-786.

10. Frölich K, Hamblin C, Parida S, Tuppurainen E, Schettler E: Serological survey for potential disease agents of free-ranging cervids in six selected national parks from Germany. J Wildl Dis 2006, 42(4):836-843.

11. Krametter R, Nielsen SS, Loitsch A, Froetscher W, Benetka V, Moestl K, Baumgartner W: Pestivirus exposure in free-living and captive deer in Austria. J Wildl Dis 2004, 40(4):791-795.

12. Gaffuri A, Giacometti M, Tranquillo VM, Magnino S, Cordioli P, Lanfranchi P: Serosurvey of roe deer, chamois and domestic sheep in the central Italian Alps. J Wildl Dis 2006, 42(3):685-690.

13. Olde Riekerink RGM, Dominici A, Barkema HW, de Smit AJ: Seroprevalence of pestivirus in four species of alpine wild ungulates in the High Valley of Susa, Italy. Vet Microbiol 2005, 108(3-4):297-303.

14. Marco I, Rosell R, Cabezón O, Beneria M, Mentaberre G, Casas E, Hurtado A, López-Olvera JR, Lavín S: Serologic and virologic investigations into pestivirus infection in wild and domestic ruminants in the Pyrenees (NE Spain). Res Vet Sci 2009, 87(1):149-153.

15. Marco I, Cabezón O, Rosell R, Fernández-Sirera L, Allepuz A, Lavín S: Retrospective study of pestivirus infection in Pyrenean chamois (Rupicapra pyrenaica) and other ungulates in the Pyrenees (NE Spain). Vet Microbiol.

16. Thiry J, Widén F, Gregoire F, Linden A, Belák S, Thiry E: Isolation and characterisation of a ruminant alphaherpesvirus closely related to bovine herpesvirus 1 in a free-ranging red deer. BMC Vet Res 2007, 3:26

17. Ruiz-Fons F, Reyes-Garcia AR, Alcaide V, Gortazar C: Spatial and temporal evolution of bluetongue virus in wild ruminants, Spain. Emerg Infect Dis 2008, 14(6):951-953.

18. Linden A, Gregoire F, Nahayo A, Hanrez D, Mousset B, Massart A, De Leeuw I, Vandemeulebroucke E, Vandenbussche F, De Clercq K: Bluetongue virus in wild deer, Belgium, 2005-2008. Emerg Infect Dis 2010, 16(5):833-836.
19. Kopecna M, Trcka I, Lamka J, Moravkova M, Koubek P, Heroldova M, Mrlik V, Kralova A, Pavlik I: The wildlife hosts of Mycobacterium avium subsp. paratuberculosis in the Czech Republic during the years 2002-2007. Veterinarni Medicina 2008, 53(8):420-426.

20. Tryland M, Olsen I, Vikoren T, Handeland K, Arnemo JM, Tharaldsen J, Djonne B, Josefsen TD, Reitan $\sqcup$ : Serologic survey for antibodies against Mycobacterium avium subsp paratuberculosis in free-ranging cervids from Norway. J Wildl Dis 2004, 40(1):32-41.

21. Robino P, Nebbia P, Tramuta C, Martinet M, Ferroglio E, De Meneghi D: Identification of Mycobacterium avium subsp. paratuberculosis in wild cervids (Cervus elaphus hippelaphus and Capreolus capreolus) from Northwestern Italy. Eur J Wildl Res 2008, 54(2):357-360.

22. Diéguez FJ, Arnaiz I, Sanjuán ML, Vilar MJ, López M, Yus E: Prevalence of serum antibodies to Mycobacterium avium subsp. paratuberculosis in cattle in Galicia (northwest Spain). Prev Vet Med 2007, 82(3-4):321-326.

23. Ferroglio E, Gennero MS, Pasino M, Bergagna S, Dondo A, Grattarola C, Rondoletti M, Bassano B: Cohabitation of a Brucella melitensis infected Alpine ibex (Capra ibex) with domestic small ruminants in an enclosure in Gran Paradiso national park, in Western Italian Alps. Eur J Wildl Res 2007, 53(2):158-160.

24. Lopez-Olvera JR, Vidal D, Vicente J, Perez M, Lujan L, Gortazar C: Serological survey of selected infectious diseases in mouflon (Ovis aries musimon) from south-central Spain. Eur J Wildl Res 2009, 55(1):75-79.

25. Munoz P, Boadella M, Arnal M, de Miguel M, Revilla M, Martinez D, Vicente J, Acevedo P, Oleaga A, Ruiz-Fons F, et al: Spatial distribution and risk factors of Brucellosis in Iberian wild ungulates. BMC Infect Dis 2010, 10(1):46.

26. Erdélyi K, Dencso L, Lehoczki R, Heltai M, Sonkoly K, Csányi S, Solymosi N: Endemic papillomavirus infection of roe deer (Capreolus capreolus). Vet Microbiol 2009.

27. Ruiz-Fons F, Rodriguez O, Torina A, Naranjo V, Gortazar C, de la Fuente J: Prevalence of Coxiella burnetti infection in wild and farmed ungulates. Vet Microbiol 2008, 126(1-3):282-286.

28. Salinas J, Caro MR, Vicente J, Cuello F, Reyes-Garcia AR, Buendía AJ, Rodolakis A, Gortázar C: High prevalence of antibodies against Chlamydiaceae and Chlamydophila abortus in wild ungulates using two "in house" blocking-ELISA tests. Vet Microbiol 2009, 135(1-2):46-53.

29. de la Fuente J, Ruiz-Fons F, Naranjo V, Torina A, Rodríguez O, Gortázar C Evidence of Anaplasma infections in European roe deer (Capreolus capreolus) from southern Spain. Res Vet Sci 2008, 84(3):382-386.

30. Gauss CBL, Dubey JP, Vidal D, Cabezon O, Ruiz-Fons F, Vicente J, Marco I, Lavin S, Gortazar C, Almeria S: Prevalence of Toxoplasma gondii antibodies in red deer (Cervus elaphus) and other wild ruminants from Spain. Vet Parasitol 2006, 136(3-4):193-200.

31. Gamarra JA, Cabezon O, Pabon M, Arnal MC, Luco DF, Dubey JP, Gortazar C, Almeria S: Prevalence of antibodies against Toxoplasma gondii in roe deer from Spain. Vet Parasitol 2008, 153(1-2):152-156.

32. Bartova E, Sedlak K, Pavlik I, Literak I: Prevalence of Neospora caninum and Toxoplasma gondii antibodies in wild ruminants from the countryside or captivity in the Czech Republic. J Parasitol 2007, 93(5):1216-1218,

33. Vikøren T, Tharaldsen J, Fredriksen B, Handeland K: Prevalence of Toxoplasma gondii antibodies in wild red deer, roe deer, moose, and reindeer from Norway. Vet Parasitol 2004, 120(3):159-169.

34. Jokelainen P, Nareaho A, Knaapi S, Oksanen A, Rikula U, Sukura A: Toxoplasma gondii in wild cervids and sheep in Finland: North-south gradient in seroprevalence. Vet Parasitol 2010, 171(3-4):331-336.

35. Aubert D, Ajzenberg D, Richomme C, Gilot-Fromont E, Terrier ME, de Gevigney C, Game Y, Maillard D, Gibert P, Dardé ML, et al: Molecular and biological characteristics of Toxoplasma gondii isolates from wildlife in France. Vet Parasitol 2010, 171(3-4):346-349.

36. Panadero R, Painceira A, López C, Vázquez L, Paz A, Díaz P, Dacal V, Cienfuegos S, Fernández G, Lago N, et al: Seroprevalence of Toxoplasma gondii and Neospora caninum in wild and domestic ruminants sharing pastures in Galicia (Northwest Spain). Res Vet Sci 2010, 88(1):111-115.

37. Almería $S$, Vidal D, Ferrer D, Pabón M, Fernández-de-Mera MIG, Ruiz-Fons F, Alzaga V, Marco I, Calvete C, Lavin S, et al: Seroprevalence of Neospora caninum in non-carnivorous wildlife from Spain. Vet Parasitol 2007, 143(1):21-28.

38. San José C: Capreolus capreolus. In Atlas de los mamíferos terrestres de España. Edited by: LJ Palomo JG. Spain: Dirección General de la Conservación de la Naturaleza-SECEM-SECEMU; 2002. 
39. Mussa PP, Aceto P, Abba C, Sterpone L, Meineri G: Preliminary study on the feeding habits of roe deer (Capreolus capreolus) in the western Alps. J Anim Physiol Anim Nutr 2003, 87(3-4):105-108.

40. Delahay RJ, Smith GC, Barlow AM, Walker N, Harris A, Clifton-Hadley RS, Cheeseman CL: Bovine tuberculosis infection in wild mammals in the South-West region of England: A survey of prevalence and a semiquantitative assessment of the relative risks to cattle. Vet J 2007, 173(2):287-301.

41. Artois $M$, Bengis $R$, Delahay $R$, Duchêne $M$, Duff $P$, Ferroglio $E$, Gortazar $C$, Hutchings $M$, Kock $R$, Leighton T, et al: Wildlife disease surveillance and monitoring. In Management of Disease in Wild Mammals. Edited by: Delahay R, Smith G, Hutchings M. New York: Springer; 2009:284.

42. Saenz de Buruaga M, Lucio AJ, Purroy FJ: Reconocimiento de sexo y edad en especies cinegéticas.Edited by: Ediciones Leonesas SA , 11991.

43. Reyes-Garcia R, Perez-de-la-Lastra JM, Vicente J, Ruiz-Fons F, Garrido JM, Gortazar C: Large-scale ELISA testing of Spanish red deer for paratuberculosis. Vet Immunol Immunopathol 2008, 124(1-2):75-81.

44. Reiczigel J: Confidence intervals for the binomial parameter: some new considerations. Stat Med 2003, 22(4):611-621.

45. Stallknecht DE: Impediments to wildlife disease surveillance, research, and diagnostics. Wildlife and Emerging Zoonotic Diseases: The Biology, Circumstances and Consequences of Cross-Species Transmission 2007, 315:445-461.

46. García-Pérez AL, Barandika JF, Aduriz G, Barral M, Benedicto L, Moreno B, García J: Diagnóstico de la enfermedad de Border en dos rebaños ovinos. Producción Ovina y Caprina 2000, 25:425-428.

47. Valdazo-González B, Álvarez-Martínez M, Greiser-Wilke I: Genetic typing and prevalence of Border disease virus (BDV) in small ruminant flocks in Spain. Vet Microbiol 2006, 117(2-4):141-153.

48. Pioz M, Loison A, Gibert P, Dubray D, Menaut P, Le Tallec B, Artois M, GilotFromont $E$ : Transmission of a pestivirus infection in a population of Pyrenean chamois. Vet Microbiol 2007, 119(1):19-30.

49. Sedlak K, Girma T, Holejsovsky J: Pestivirus infections in cervids from the Czech Republic. Veterinarni Medicina 2009, 54(4):191-193.

50. Fischer $\mathrm{S}$, Weiland E, Frölich K: Characterization of a bovine viral diarrhea virus isolated from roe deer in Germany. J Wildl Dis 1998, 34(1):47-55.

51. García I, Napp S, Casal J, Perea A, Allepuz A, Alba A, Carbonero A, Arenas A: Bluetongue epidemiology in wild ruminants from Southern Spain. Eur $J$ Wildl Res 2009, 55(2):173-178.

52. Marco I, Ruiz M, Juste R, Garrido JM, Lavin S: Paratuberculosis in freeranging fallow deer in Spain. J Wildl Dis 2002, 38(3):629-632.

53. Balseiro A, García Marín JF, Solano P, Garrido JM, Prieto JM: Histopathological classification of lesions observed in natural cases of paratuberculosis in free-ranging Fallow Deer (Dama dama). J Comp Pathol 2008, 138(4):180-188.

54. Falconi C, Oleaga Á, López-Olvera JR, Casais R, Prieto M, Gortázar C: Prevalence of antibodies against selected agents shared between Cantabrian chamois (Rupicapra pyrenaica parva) and domestic goats. Eur J Wildl Res 2010, 56(3):319-325.

55. Grewal SK, Rajeev S, Sreevatsan S, Michel FC Jr: Persistence of Mycobacterium avium subsp. paratuberculosis and other zoonotic pathogens during simulated composting, manure packing, and liquid storage of dairy manure. Appl Environ Microbiol 2006, 72(1):565-574.

56. Katayama N, Suzuki T, Ootake M, Shibata M, Kamata S, Yokomizo Y: Influence of ultraviolet-B (UV-B) on viability of Mycobacterium avium subsp paratuberculosis. Proceedings of the Seventh International Colloquium on Paratuberculosis 2003, 481-485.

57. Corn JL, Manning EJB, Sreevatsan S, Fischer JR: Isolation of Mycobacterium avium subsp. paratuberculosis from free-ranging birds and mammals on livestock premises. Appl Environ Microbiol 2005, 71(11):6963-6967.

58. Conraths FJ, Gethmann JM, Staubach C, Mettenleiter TC, Beer M, Hoffmann B: Epidemiology of Bluetongue Virus Serotype 8, Germany. Emerg Infect Dis 2009, 15(3):433-435.

59. Blasco JM, Garinbastuji B, Marin CM, Gerbier G, Fanlo J, Debagues MPJ, Cau C: Efficacy of different rose-bengal and complement-fixation antigens for the diagnosis of Brucella melitensis infection in sheep and goats. Vet Rec 1994, 134(16):415-420.

doi:10.1186/1746-6148-6-51

Cite this article as: Boadella et al: Serosurvey for selected pathogens in Iberian roe deer. BMC Veterinary Research 2010 6:51.

\section{Submit your next manuscript to BioMed Central and take full advantage of:}

- Convenient online submission

- Thorough peer review

- No space constraints or color figure charges

- Immediate publication on acceptance

- Inclusion in PubMed, CAS, Scopus and Google Scholar

- Research which is freely available for redistribution 